\title{
RESEARCH
}

Open Access

\section{Knowledge and attitudes towards antibiotic use and resistance among undergraduate healthcare students at University of Rwanda}

Lyduine Nisabwe ${ }^{1}$, Hirwa Brice ${ }^{1}$, Marie Christine Umuhire ${ }^{1}$, Olivia Gwira', Jean De Dieu Harelimana², Zephanie Nzeyimana ${ }^{3}$, Osee Rurambya Sebatunzi ${ }^{4}$, Emmanuel Kamanzi Rusingiza ${ }^{5}$, Innocent Hahirwa ${ }^{1}$ and Claude Mambo Muvunyi ${ }^{6^{*}}$

\begin{abstract}
Background: Antimicrobial resistance (AMR) is an imminent threat to modern medicine. As the efficacy of treatment regimens is reduced, mortality and morbidity attributed to infectious diseases is expected to rise dramatically across the globe. Antimicrobial stewardship and good prescription practices are critical to conserving available therapeutics; it is appropriate, therefore, to appraise our attitudes and knowledge of antimicrobial resistance, particularly for the future healthcare practitioners.

Methods: This is a descriptive cross-sectional study that was conducted among 282 medicals, dental and pharmacy students from the University of Rwanda. Questionnaires were used to collect data from the 4th to 29th March 2017.

Results: Students from Level 3 to level 6 have demonstrated a good knowledge on antibiotics and antimicrobial resistance. Generally, $95 \%(n=218)$ agreed that the inappropriate use of antibiotics could lead to antibiotic resistance. It was found that $96 \%(n=220)$ of the respondents had heard about AMR outside their degree courses. $49 \%(n=112)$ of the participants reported that they are able to purchase antibiotics without a prescription. $96 \%$ $(n=220)$ agreed that it was important for healthcare students to be knowledgeable about antimicrobial resistance. Perhaps most surprisingly, it was found that $83 \%(n=191)$ of participants were unfamiliar with the concept of antimicrobial stewardship and $49 \%(n=21)$ had not yet discussed antimicrobial resistance as part of their education, albeit only $1 \%(n=3)$ was completely unfamiliar with the term. Furthermore, 38\% $(n=86)$ did not support that the antibiotics were overused in Rwanda, 23\% $(n=10)$ did not agree that inappropriate antimicrobial use contributed to antimicrobial resistance, and $50 \%(n=22)$ of participants agreed that antibiotics were indicated in the treatment of pain and inflammation.

\footnotetext{
* Correspondence: clmuvunyi@gmail.com

${ }^{6}$ Department of Clinical Biology, School of Medicine and Pharmacy, College of Medicine and Health Sciences, University of Rwanda, Kigali, Rwanda

Full list of author information is available at the end of the article
}

C C The Author(s). 2020 Open Access This article is licensed under a Creative Commons Attribution 4.0 International License, which permits use, sharing, adaptation, distribution and reproduction in any medium or format, as long as you give appropriate credit to the original author(s) and the source, provide a link to the Creative Commons licence, and indicate if changes were made. The images or other third party material in this article are included in the article's Creative Commons licence, unless indicated otherwise in a credit line to the material. If material is not included in the article's Creative Commons licence and your intended use is not permitted by statutory regulation or exceeds the permitted use, you will need to obtain permission directly from the copyright holder. To view a copy of this licence, visit http://creativecommons.org/licenses/by/4.0/ The Creative Commons Public Domain Dedication waiver (http://creativecommons.org/publicdomain/zero/1.0/) applies to the data made available in this article, unless otherwise stated in a credit line to the data. 
(Continued from previous page)

Conclusions: The present study reports a moderate knowledge on AMR among the healthcare students. The gaps in the current formal training of healthcare individuals have been identified as well. We highlight the necessity to enhance educational approaches to introduce the key concepts of AMR and antimicrobial stewardship to the curriculum of healthcare students.

Keywords: Antibiotic use, Antimicrobial resistance, Undergraduate students, Knowledge, And attitude

\section{Introduction}

Antimicrobial resistance is a natural biological phenomenon when microbes are no longer killed by an antimicrobial to which they were previously sensitive, often due to the genetic mutations of microorganisms $[1,2]$. This phenomenon frequently occurs when the antimicrobials are misused. The resistant mutants are often considered as "superbugs" [3].

Antimicrobial resistance is a global crisis that requires global coordinated efforts. Although the WHO's Global action plan on antimicrobial resistance is being formulated [4]. The current studies have reported dramatic increase of antimicrobial resistance especially in resources limited countries [5]. There is a growing body of literature that accents the significance of resistance to antibiotics that are commonly prescribed in lagging countries [6]. Therefore, there is an urgent need to address antimicrobial resistance in developing countries especially in Africa due to the fact that it is being overlooked and yet highly linked high morbidity and mortality [7]. A great demand of broad-spectrum agents due to ineffectiveness of certain antibiotics on which specific pathogens have developed resistance $[6,8]$, poses an economic burden on developing countries [7].

A study conducted among medical students in Democratic republic of Congo (DRC) showed that medical students are aware of antibiotics overuse and that it would be of significance to raise awareness of antibiotics among these future prescribers [9]. Evidence suggests that strategic actions such as antimicrobial stewardship must be enforced. Another study carried out in India has revealed a gap in the knowledge regarding antibiotic use among medical and dental students. Thus, they recommended to reinforce the curriculum by introducing more lectures on antimicrobial stewardship [10].

Furthermore, A study conducted at a tertiary healthcare hospital in Rwanda, reported high rate of AMR and highlighted the need for rational use of antibiotics, implementation of antimicrobial surveillance programs, and appropriate infection control measures to tackle AMR [11].

In some countries such as Albania and Pakistan, selfpurchasing of antibiotic was predominant among fresh pharmacists $[12,13]$. A study conducted among undergraduate and postgraduate pharmacy students in southern
India highlighted the need to integrate specific lectures on appropriate use of antibiotics in pharmacy programs [14]. Similarly, findings from other studies conducted in South Africa and Bangladesh, stated that training opportunities and standardized curricula on antimicrobial stewardship, as educational interventions, would boost the knowledge of medical students and strengthen their confidence on antimicrobial prescribing $[15,16]$.

Different studies have associated antimicrobial resistance with the level of knowledge, attitudes and perceptions on antimicrobial use in healthcare provider while others have highlighted patient pressure and failure to complete the full course of treatment as two main factors that contribute to drug resistance $[5,17]$. Healthcare students as future prescribers and dispensers of antimicrobials may have a different perspective on the matter. Globally, self-medication remains at the top of the main cause of AMR because antibiotics are still being overthe-counter dispensed in many settings $[18,19]$.

Limited evidence from African countries suggests that self-medication with antibiotics is a common health-seeking behavior and patients directly reach out to pharmacists without medical consultation due to the inability of affording healthcare services [20] . The challenge of having a limited number of certified pharmacists able to provide proper patient counselling on the use of antimicrobials is another raison for irrational use of antibiotics [21].

Therefore, improving the knowledge of healthcare students especially pharmacy students is crucial in the fight against AMR [22]. In addition, pharmacists are well placed to forefend AMR by encouraging the rational use of antimicrobials as reported by WHO [23]. Well educated pharmacists can contribute to the reduction of irrational use of antimicrobials, hence improving pharmacist's role in the healthcare system of developing countries is decisive in the battle against AMR globally [24].

It is important to highlight that in Rwanda, healthcare students are allowed to practice right after their graduation. Thus, it would be of significance to know their knowledge regarding antimicrobials use. The present study aimed to evaluate the level of knowledge, attitudes and perceptions of healthcare students towards antimicrobial use and resistance in Rwanda. 


\section{Materials and methods}

\section{Study setting, design and population}

This was a descriptive cross-sectional study that included Medicine, pharmacy and dentistry students from the University of Rwanda. Sample size was determined by using the formula below considering the $P$ value of $50 \%$ for antibiotics use giving total sample size of 282 .

$$
\mathrm{n}=\left[\mathrm{z}^{2} * \mathrm{p} *(1-\mathrm{p}) / \mathrm{e}^{2}\right] /\left[1+\left(\mathrm{z}^{2} * \mathrm{p} *(1-\mathrm{p}) /\left(\mathrm{e}^{2} * \mathrm{~N}\right)\right)\right]
$$

Where: $N=1051$ (population size); $\mathrm{z}=1.96$ for a confidence level $(\alpha)$ of $95 \%, p=0.5$ proportion (expressed as a decimal); $\mathrm{e}=$ margin of error.

$$
\begin{aligned}
& \mathrm{z}=1.96, \mathrm{p}=0.5, \mathrm{~N}=1051, \mathrm{e}=0.05 \\
& \mathrm{n}=\left[1.96^{2} * 0.5 *(1-0.5) / 0.05^{2}\right] / 1 \\
& \left.+\left(1.96^{2} * 0.5 *(1-0.5) /\left(0.05^{2} * 1051\right)\right)\right] \\
& n=384.16 / 1.3655=281.329 \\
& \mathrm{n} \approx 282
\end{aligned}
$$

Stratified sampling technique was used to select representative classes. The total sample size of 229 participants was distributed among selected classes according to class size. Finally, the study subjects were selected using systematic random sampling technique. 229 participants who responded to the questionnaire.

\section{Data collection tool}

A questionnaire of both close-ended and open-ended questions from other studies were adapted and adjusted and administered to participants to collect relevant information. The questionnaire consisted of four sections. The first section explored the demographic characteristics and information related to antibiotic use. The second section comprised questions aiming to evaluate knowledge of participants about antimicrobials and resistance. The third section was to assess the resources for Antimicrobial resistance awareness. The last part was made of sixteen questions aiming to assess the attitudes and perceptions towards antimicrobial use and prescription. Introduction of the study and its objectives was done prior to distribution of questionnaires to the participants.

\section{Data analysis}

Prior to data analysis, questions were grouped according to assessed parameters: respondent characteristics, knowledge about antibiotics and resistance, source of information on antimicrobial resistance, attitudes and perceptions regarding antimicrobial use and resistance.
Data were captured and analyzed using both Statistical Package for Social Sciences (SPSS V.16.0) software and Microsoft Excel 2010.

\section{Ethical consideration}

Kigali University Teaching Hospital ethical committee approved the research proposal and the permission from the University of Rwanda was also granted. Participation of the present study was voluntary, and each participant signed a consent form.

\section{Results}

Table 1 shows details on demographic characteristics of the study population. Females were $40.17 \%$ and males were $59.83 \%$. The half of respondents was medical students while dentistry was the least represented (18\%). Respondents were from all class levels with first 2 years representing $44 \%$ of participants. As far as the use of antibiotics in the previous year is concerned, $41 \%$ of students reported that they had used

\begin{tabular}{|c|c|c|}
\hline Respondents' characteristics & Frequency & Percentage \\
\hline \multicolumn{3}{|l|}{ Gender } \\
\hline Male & 137 & 59.83 \\
\hline Female & 92 & 40.17 \\
\hline \multicolumn{3}{|l|}{ Degree course/Department } \\
\hline Medicine & 115 & 50.22 \\
\hline Dentistry & 41 & 17.9 \\
\hline Pharmacy & 73 & 31.88 \\
\hline \multicolumn{3}{|l|}{ Year of study/Level } \\
\hline First & 51 & 22.27 \\
\hline Second & 50 & 21.83 \\
\hline Third & 31 & 13.54 \\
\hline Fourth & 52 & 22.71 \\
\hline Fifth & 30 & 13.1 \\
\hline Sixth & 15 & 6.55 \\
\hline \multicolumn{3}{|c|}{ Do you have a family in health field? } \\
\hline Yes & 86 & 37.55 \\
\hline No & 143 & 62.45 \\
\hline \multicolumn{3}{|c|}{ How often have you used antibiotics? } \\
\hline $1-2$ times & 93 & 40.61 \\
\hline $3-5$ times & 29 & 12.66 \\
\hline More than 5 times & 17 & 7.42 \\
\hline Never & 90 & 39.3 \\
\hline
\end{tabular}
antibiotics one to two times and 13\% admitted having used them three to five times. A relatively small number of respondents (7\%) reported to have used antibiotics more than five times in the previous year while

Table 1 Respondents' distribution 
$31 \%$ of participants never used them. Almost twothirds of participants had no family member working in Health field.

As it can be depicted from Table 2, the highest percentage of fully correct answers ("Strongly agree" and "Strongly disagree") was around $62 \%$. Only $41.9 \%$ of respondents disagreed with this statement "Antibiotics are indicated to reduce any kind of pain and inflammation".

As it is described in Table 3, respondents demonstrated a remarkable and satisfactory knowledge in identifying whether Amoxicillin and Penicillin were antibiotics or not, where more than $90 \%$ responded correctly to related statement. However, surprisingly $20 \%$ of the participants classified Aspirin among antibiotics.

As it is shown in Table 4, the responses obtained when participants were asked whether an inappropriate use of antimicrobials could cause antimicrobial resistance were quite interesting and promising as this was confirmed by $95 \%$ of the respondents. The great majority of respondents (89.5\%) admitted that poor infection control practices contribute to Antimicrobial resistance while 59.8\% agreed that antimicrobials are overused in Rwanda. Surprisingly none of the respondents knew what antimicrobial stewardship is and even the 34 participants who

Table 2 Knowledge of respondents on Antibiotics

\begin{tabular}{llllll}
\hline $\begin{array}{l}\text { Knowledge } \\
\text { statement }\end{array}$ & $\begin{array}{l}\text { Strongly } \\
\text { agree } \\
(\%)\end{array}$ & $\begin{array}{l}\text { Agree } \\
(\%)\end{array}$ & $\begin{array}{l}\text { Uncertain } \\
(\%)\end{array}$ & $\begin{array}{l}\text { Disagree } \\
(\%)\end{array}$ & $\begin{array}{l}\text { Strongly } \\
\text { disagree } \\
(\%)\end{array}$ \\
\hline $\begin{array}{l}\text { Antibiotics are } \\
\text { useful for } \\
\text { bacterial }\end{array}$ & $143(62.4)$ & $67(29.3)$ & $4(1.7)$ & $8(3.5)$ & $7(3.1)$ \\
infections (e.g. \\
$\begin{array}{l}\text { Tuberculosis) } \\
\text { Antibiotics are }\end{array}$ & $10(4.4)$ & $33(14.4)$ & $15(6.6)$ & $48(21.0)$ & $123(53.7)$ \\
$\begin{array}{l}\text { useful for viral } \\
\text { infections } \\
\text { (e.g.flu). }\end{array}$ & & & & & \\
$\begin{array}{l}\text { Antibiotics are } \\
\text { indicated to }\end{array}$ & $11(4.8)$ & $39(17)$ & $22(9.6)$ & $61(26.6)$ & $96(41.9)$ \\
reduce any kind \\
of pain and \\
inflammation.
\end{tabular}

Table 3 Knowledge of respondents on AntibioticsIdentification of antibiotics

\begin{tabular}{llll}
\hline Knowledge statement & Yes (\%) & No (\%) & $\begin{array}{l}\text { Don't Know } \\
(\%)\end{array}$ \\
\hline $\begin{array}{l}\text { Penicillin or Amoxicillin are } \\
\text { antibiotics }\end{array}$ & $216(94.3)$ & $8(3.5)$ & $5(2.2)$ \\
Aspirin is an antibiotic & $38(16.6)$ & $184(80.3)$ & $7(3.1)$ \\
Paracetamol is an antibiotic & $13(5.7)$ & $213(93.0)$ & $3(1.3)$ \\
\hline
\end{tabular}

answered yes to the question, failed to correctly explain its meaning.

The following Table 5, details the respondents' views on whether antibiotics can be used to reduce any kind of pain and inflammation, this statement was used to evaluate students' knowledge on antibiotics according to their level of study and programs. The majority of the right answers to the related were from higher levels of study (level 3 to 6) indicting with no surprise, that students in lower levels have a low level of knowledge regarding antibiotics. In addition to that, as shown in Table 5, the rate of correct answers was higher in Pharmacy students compared to medical and dental students.

As it is recapitulated in Table 6, almost all respondents reported to have heard about antimicrobial resistance before, $78.9 \%$ of said that they have discussed about it during degree courses. Among the respondents $96.1 \%$ indicated that they had heard about AMR outside degree courses.

Table 7 describes the attitudes and perceptions regarding antimicrobial use and resistance. Only 15\% reported that the usually use antibiotics for fever whereas $27 \%$ admitted that they have used antibiotics to treat cold or sore throat. Around three-quarters reported that they don't keep leftovers antibiotics for a possible future use.

Self-medication was reported by almost half of the participants who admitted having purchased antibiotics without a medical prescription.

\section{Discussion}

This study aimed to evaluate the knowledge and attitudes towards antibiotic use and resistance among healthcare students in Rwanda. To date, there is no other study that attempted to tackle this topic in the country. It was evident that even for the students who seem to be knowledgeable on AMR, proper use of antibiotics is not reflected in their daily life. However, the respondents showed an important interest to acquire more skills on antimicrobial use, prescribing and resistance. They were conscientious on the fact that, as future healthcare providers, they would participate in the fight against AMR starting from their early education. 
Table 4 Knowledge on antimicrobial resistance

\begin{tabular}{|c|c|c|}
\hline Knowledge question & Yes (\%) & No (\%) \\
\hline Are antimicrobials overused in Rwanda? & 137(59.8) & $86(37.6)$ \\
\hline Can inappropriate use of antimicrobials cause antimicrobial resistance? & 218(95.2) & $11(4.8)$ \\
\hline Do you think it is important for the prescriber to do an antibiogram before prescribing antibiotic? & 202(88.2) & 26(11.4) \\
\hline Do poor infection control practices contribute to antimicrobial resistance? & 205(89.5) & 23(10) \\
\hline Do you know what antimicrobial stewardship means? & $34(14.8)$ & 191(83.4) \\
\hline
\end{tabular}

The findings of this study are in accordance with those reported in studies conducted in India respectively among medical, dental and pharmacy students; that suggested the review of curricula in undergraduate classes to boost their knowledge on antimicrobial use and prescribing $[10,14]$. In fact, when current study participants were asked if "Antibiotics are indicated to reduce any kind of pain and inflammation", a correct answer was obtained from only $41.9 \%$ of respondents. Additionally, $62.4 \%$ of the respondents strongly agreed that the antibiotics could be used to treat bacterial infections. A possible explanation for these results may be the lack of adequate resources to learn about antimicrobials. More so, differences may be attributed to the absence of strict and enforced laws and regulations on how antibiotics are prescribed and dispensed in retail pharmacies in Rwanda.

The present study revealed that only $59.8 \%$ of the students concur with the statement that antimicrobials are overused in Rwanda, a rate far lower than that $(90 \%)$ reported in a study conducted in Democratic republic of Congo among medical students and medical doctors [9].

This discrepancy may simply be attributed to lack of information on antimicrobial use.

Concerning antimicrobial susceptibility testing, $88.2 \%$ of respondents stressed that it is important to perform the test before prescribing any antibiotic.
These findings are in fact very encouraging given the fact that antimicrobials are overprescribed and that medical and dental students, as future prescribers they are aware that prescribing antibiotics in a noncontrolled way is not a good practice. Instantly development of new educational strategies for healthcare students to fight AMR is needed at university level for changing antimicrobial prescription behaviors and ensuring proper antimicrobial usage.

Regarding attitudes and perceptions towards antimicrobial use and resistance, $15 \%$ of students reported to have used antibiotics to treat fever. These findings are in line with the study conducted in Trinidad and Tobag [25]. This can partially explain the high rate of students who reported to have used Aspirin as an antibiotic and the $27 \%$ of respondents who used antibiotics to treat cold and sore throat. These factors may explain the relatively good correlation between the use of antibiotics to treat common cold and flu and the failure to differentiate antibiotics from non-steroidal anti-inflammatory drugs (NSAIDs) and painkillers. Around $80 \%$ of respondents reported not to keep leftover antibiotics for use in the future or for treating colds and flu.

However, almost a half of all study participants reported that they can use antibiotics without a medical prescription, this is in agreement with previous findings which have proved that self-medication is not only done

Table 5 Results of the question "Antibiotics are indicated to reduce any kind of pain or inflammation" according to the year of studies and department

\begin{tabular}{|c|c|c|c|c|c|c|}
\hline Department & Level & $\begin{array}{l}\text { Strongly disagree } \\
(\%)\end{array}$ & $\begin{array}{l}\text { Disagree } \\
(\%)\end{array}$ & $\begin{array}{l}\text { Uncertain } \\
\text { (\%) }\end{array}$ & $\begin{array}{l}\text { Agree } \\
(\%)\end{array}$ & Strongly agree (\%) \\
\hline \multirow[t]{2}{*}{ Medicine } & $\begin{array}{l}\text { Pre-clinical } \\
(n=39)\end{array}$ & $13(33.3)$ & $12(30.8)$ & $5(12.8)$ & $5(12.8)$ & $4(10.2)$ \\
\hline & $\begin{array}{l}\text { Clinical } \\
(n=50)\end{array}$ & $31(62)$ & 13(26) & $2(4)$ & $3(6)$ & $1(2)$ \\
\hline \multirow[t]{2}{*}{ Pharmacy } & $\begin{array}{l}\text { Low level } \\
(n=43)\end{array}$ & $27(62.8)$ & $11(25.7)$ & $2(4.6)$ & $2(4.6)$ & $1(2.3)$ \\
\hline & $\begin{array}{l}\text { Advanced } \\
\text { level }(n=42)\end{array}$ & $42(100)$ & $0(0)$ & $0(0)$ & $0(0)$ & $0(0)$ \\
\hline \multirow[t]{2}{*}{ Dentistry } & $\begin{array}{l}\text { Low level } \\
(n=23)\end{array}$ & $4(17.4)$ & $5(21.8)$ & $1(4.3)$ & $9(39.1)$ & $4(17.4)$ \\
\hline & $\begin{array}{l}\text { Advanced level } \\
n=32\end{array}$ & $12(37.5)$ & 12(37.5) & $5(15.6)$ & $2(6.25)$ & $1(3.1)$ \\
\hline
\end{tabular}


Table 6 Sources of information on AMR awareness

\begin{tabular}{lll}
\hline Knowledge statement & Yes (\%) & No (\%) \\
\hline Have you ever heard about antibiotic resistance? & $226(98.7)$ & $3(1.3)$ \\
Have you discussed about antibiotic resistance during your course? & $180(78.6)$ & 49(21.4) \\
Do you have a course of antimicrobial resistance in your curriculum? & $141(61.4)$ & 88(38.4) \\
Have you ever heard about AMR out of your degree courses? & $220(96.1)$ \\
Do you think healthcare students should be knowledgeable about AMR? & $220(96.1)$ & $7(3.9)$ \\
Do you think general knowledge should be considered when prescribing antibiotics? & $210(91.7)$
\end{tabular}

by non-medical students [26]. These findings are rather disappointing because self-medication is among the leading causes of AMR [8].

Despite the fact that Rwandans have access to a public insurance scheme with low copayments, the lengthy of the insurance clearings before getting a health service as well as the easy accessibility of community pharmacies compared to health facilities, may contribute to selfpurchasing.

Results on attitudes and perceptions on antimicrobial use and resistance are also in agreement with previous studies which proved that healthcare students had knowledge on antimicrobials but demonstrated poor attitudes towards antimicrobial use and resistance [27]. This lack of correlation between knowledge and attitude towards antimicrobial resistance have been reported in several other studies including a Kosovo study which illustrated that pharmacy students have uncommendable behaviors with regards to self-medication despite of the good theoretical knowledge on AMR [28].

Students admitted that AMR is now a global threat and were aware of the burden that may result from its rise. This study is consistent with two studies conducted in Southern India and South Africa which reported that healthcare students are aware that inappropriate use of antimicrobials may be harmful to patients and can cause antimicrobial resistance $[15,27]$.
Almost all respondents reported that apart from learning about AMR from degree courses, they have heard about it from media. A survey conducted at the University of Torino revealed that healthcare students do not have a course specifically focusing on antibiotic resistance [17]. This matches with the reality observed in healthcare students' curricula in Rwanda, the topic of AMR is discussed in several degree courses, such as "Pharmacology" or "Infectious diseases course" in which likely the antibiotics can be discussed; but there is no specific course focusing on antimicrobial resistance except for Pharmacy students which may explain their better knowledge on AMR compared to other healthcare students.

Moreover, strengthening antimicrobial stewardships in all health facilities would create an continual platform of discussion for fresh prescribers and pharmacists to draw evidence-based solutions on antimicrobial resistance $[29,30]$.

\section{Conclusion}

This study showed a good knowledge of healthcare students regarding AMR but this was not reflected into their attitudes towards antimicrobial resistance. They fail to apply their knowledge in the real life. Students in health career tend to practice self-medication pretending to know which medication to take even without consulting a healthcare provider. The present study included medical,

Table 7 Respondents' attitudes and perceptions towards antimicrobials use and resistance

\begin{tabular}{|c|c|c|}
\hline Statement & Yes (\%) & No (\%) \\
\hline Do you usually take antibiotic for cold or sore throat & $62(27.1)$ & 162(70.7) \\
\hline Do you take antibiotic for fever? & 35(15.3) & 193(84.3) \\
\hline Do you usually stop taking antibiotic when you start feeling better & 34(14.8) & 195(85.2) \\
\hline Do you take antibiotic only when prescribed by the doctor? & 137(59.8) & $91(39.7)$ \\
\hline Do you keep leftover antibiotics at home because they might be useful in the future? & $46(20.1)$ & 183(79.9) \\
\hline Do you use leftover antibiotics when you have cold, sore throat or flu without consulting your doctor? & $32(14.0)$ & 196(85.6) \\
\hline Have you shared antibiotics with another member of your family? & $48(21.0)$ & 180(78.6) \\
\hline Can you buy antibiotics without a medical prescription? & 112(48.9) & $117(51.1)$ \\
\hline Have you ever started an antibiotic therapy after a simple doctor call, without a proper medical examination? & 153(66.8) & $76(33.2)$ \\
\hline
\end{tabular}


dental and pharmacy schools only, the future studies can consider other healthcare students.

The present study recommends educational interventions to enhance the knowledge and understanding of Antimicrobial resistance and prescription including reviewing the curricula and introducing the course of Antimicrobial resistance in healthcare field curricula starting in lower levels. Finally, strict policies should be put in place to regulate the flow of antibiotics and to prevent the purchase of antibiotics without a medical prescription.

\section{Abbreviations}

AMR: Antimicrobial Resistance; FIP: International pharmaceutical Federation; LMIC: Low middle income countries; NSAIDs: Nonsteroidal anti-inflammatory drugs; SPSS: Statistical Package for the Social Sciences; WHO: World Health Organization

\section{Acknowledgements}

The authors would like to thank the management and staff of the University of Rwanda for their assistance in facilitating data collection.

\section{Authors' contributions}

$L N, H B, M C U, O G$ and $C M M$ were responsible for designing the study, supervising the data collection, performing analysis and interpretation of data, and writing the first draft of manuscript. JDH, ZN, ORS, EKR and $I H$ were actively involved in supervision of the data collection, data analysis, and revision of the initial and final manuscript. All authors read and approved the final manuscript.

\section{Funding}

The author(s) received no specific funding for this work.

\section{Availability of data and materials}

The datasets analyzed during the current study are available from the corresponding author on reasonable request.

\section{Ethics approval and consent to participate}

The study was approved by the Kigali University Teaching Hospital Ethics committee. Written informed consent was obtained from the participants.

\section{Consent for publication}

Not applicable.

\section{Competing interests}

The authors declare that they have no competing interests.

\section{Author details \\ ${ }^{1}$ Department of Pharmacy, School of Medicine and Pharmacy, College of Medicine and Health Sciences, University of Rwanda, Kigali, Rwanda. ${ }^{2}$ Department of Biomedical Laboratory Science, School of Health Science, College of Medicine and Health Sciences, University of Rwanda, Kigali, Rwanda. ${ }^{3}$ Department of Medical Laboratory Sciences, Mount Kenya University, Kigali, Rwanda. ${ }^{4}$ Department of Internal Medicine, School of Medicine and Pharmacy, College of Medicine and health Sciences, University of Rwanda, Kigali, Rwanda. ${ }^{5}$ Department of Pediatrics, School of Medicine and Pharmacy, College of Medicine and health Sciences, University of Rwanda, Kigali, Rwanda. ${ }^{6}$ Department of Clinical Biology, School of Medicine and Pharmacy, College of Medicine and Health Sciences, University of Rwanda, Kigali, Rwanda.}

Received: 26 September 2019 Accepted: 31 March 2020 Published online: 22 April 2020

\section{References}

1. Franco B, Martínez M, Rodríguez MWA. The determinants of the antibiotic resistance process. Infection and drug Resistance. Infect Drug Resist. 2009:2: $1-11$.
2. Davies J, Davies D. Origins and evolution of antibiotic Resistance. Microbiol Mol Biol Rev [Internet]. 2010;74(3):417-33. https://doi.org/10.1128/MMBR. 00016-10.

3. Ventola CL. The antibiotic resistance crisis: part 1: causes and threats. Pharm Ther J. 2015;40(4):277-83 PMC4378521.

4. Jinks T, Lee N, Sharland M, Rex J, Gertler N, Diver M, et al. A time for action: antimicrobial resistance needs global response. Bull World Health Organ. 2016;94(8):558-558A

5. Amann S, Neef K, Kohl S. Antimicrobial resistance (AMR). Eur J Hosp Pharm. 2019;26(3):175-7. https://doi.org/10.1136/ejhpharm-2018-001820.

6. Irek EO, Amupitan AA, Obadare TO, Aboderin AO. A systematic review of healthcare-associated infections in Africa: An antimicrobial resistance perspective. Afr J Lab Med. 2018;7(2). https://doi.org/10.4102/ajlm.v7i2.796.

7. Cox JA, Vlieghe E, Mendelson M, Wertheim H, Ndegwa L, Villegas MV, et al. Antibiotic stewardship in low- and middle-income countries: the same but different? Clin Microbiol Infect. 2017;23(11):812-8. https://doi.org/10.1016/j. cmi.2017.07.010

8. Oh AL, Hassali MA, Al-Haddad MS, Sulaiman SAS, Shafie AA, Awaisu A. Public knowledge and attitudes towards antibiotic usage: a cross-sectional study among the general public in the state of Penang, Malaysia. J Infect Dev Ctries. 2011;5(5):338-47. https://doi.org/10.3855/jidc.1502

9. Thriemer K, Katuala Y, Batoko B, Alworonga JP, Devlieger H, Van Geet C, et al. Antibiotic prescribing in DR Congo: a knowledge, attitude and practice survey among medical doctors and students. PLoS One. 2013;8(2): 2-9. https://doi.org/10.1371/journal.pone.0055495.

10. Sharma K, Jain P, Sharma A. Knowledge, attitude and perception of medical and dental undergraduates about antimicrobial stewardship. Indian J Pharmacol. 2015;47(6):676. https://doi.org/10.4103/0253-7613.169572.

11. Ntirenganya C, Manzi O, Muvunyi CM, Ogbuagu O. High prevalence of antimicrobial resistance among common bacterial isolates in a tertiary healthcare facility in Rwanda. Am J Trop Med Hyg. 2015;92(4):865-70. https://doi.org/10.4269/ajtmh.14-0607.

12. Hoxha I, Malaj A, Kraja B, Bino S, Oluka M, Marković-Peković V, et al. Are pharmacists' good knowledge and awareness on antibiotics taken for granted? The situation in Albania and future implications across countries. J Glob Antimicrob Resist. 2018;13(2010):240-5. https://doi.org/10.1016/j.jgar. 2018.01.019

13. Saleem Z, Hassali MA, Hashmi FK, Godman B, Saleem F. Antimicrobial dispensing practices and determinants of antimicrobial resistance: $A$ qualitative study among community pharmacists in Pakistan. Fam Med Community Heal. 2019;7(3):1-9. https://doi.org/10.1136/fmch- 2019-000138.

14. Ahmad A, Khan MU, Moorthy J, Jamshed SQ, Patel I. Comparison of knowledge and attitudes about antibiotics and resistance, and antibiotics selfpracticing between bachelor of pharmacy and doctor of pharmacy students in southern India. Pharm Pract. 2015;13(1):1-7.

15. Wasserman S, Potgieter S, Shoul E, Constant D, Stewart A, Mendelson M, et al. South African medical students' perceptions and knowledge about antibiotic resistance and appropriate prescribing: are we providing adequate training to future prescribers? South African Med J. 2017;107(5): 405-10. https://doi.org/10.7196/SAMJ.2017.

16. Hoque R, Mostafa A, Haque M. Insight of medical students of clinical years to antimicrobials prescribing and resistance in private medical school, Chittagong, Bangladesh. J Young Pharm. 2016;8(4):447-55. https://doi.org/ 10.5530/jyp.2016.4.22.

17. Scaioli G, Gualano MR, Gili R, Masucci S, Bert F, Siliquini R. Antibiotic Use: A cross-sectional survey assessing the knowledge, attitudes and practices amongst students of a school of medicine in Italy. PLoS One. 2015;10(4):112. https://doi.org/10.1371/journal.pone.0122476.

18. Oh AL, Hassali MA, Al-Haddad MS, Sulaiman SAS, Shafie AA, Awaisu A. Public knowledge and attitudes towards antibiotic usage: A crosssectional study among the general public in the state of Penang, Malaysia. J Infect Dev Ctries. 2011;5(5):338-47. https://doi.org/10.3855/ jidc. 1502

19. Torres NF, Chibi B, Middleton LE, Solomon VP, Mashamba-Thompson TP. Evidence of factors influencing self-medication with antibiotics in low and middle-income countries: a systematic scoping review. Public Health. 2019; 168:92-101. https://doi.org/10.1016/j.puhe.2018.11.018.

20. Sakeena MHF, Bennett AA, McLachlan AJ. Non-prescription sales of antimicrobial agents at community pharmacies in developing countries: a systematic review. Int J Antimicrob Agents. 2018;52(6):771-82. https://doi. org/10.1016/j.ijantimicag.2018.09.022. 
21. Chang J, Xu S, Zhu S, Li Z, Yu J, Zhang Y, et al. Assessment of nonprescription antibiotic dispensing at community pharmacies in China with simulated clients: a mixed cross-sectional and longitudinal study. Lancet Infect Dis. 2019:19(12):1345-54. https://doi.org/10.1016/S1473-

3099(19)30324-X.

22. The P, Statement FIP, Resistance A, Health O, Nations U, Assembly G. Fip Statement of Policy Control of Antimicrobial Resistance (Amr); 2017. p. 1-7.

23. WHO Regional Office for Europe. The role of pharmacist in encouraging prudent use of antibiotics and averting antimicrobial resistance: a review of policy and experience. World Heal Organ. 2014;57 Available from: http:// www.euro.who.int/en/health-topics. Last accessed date 10 Feb 2017.

24. Auta A, Hadi MA, Oga E, Adewuyi EO, Abdu-Aguye SN, Adeloye D, et al. Global access to antibiotics without prescription in community pharmacies: a systematic review and meta-analysis. J Inf Secur. 2019;78(1):8-18. https:// doi.org/10.1016/j.jinf.2018.07.001.

25. Ahmad A, et al. Knowledge,attitude and practice of B. Sc Pharmacy students about antibiotics in Trinidad and Tobago. Pharm Pract (Granada). 2015;4(1): 37-41. https://doi.org/10.4103/2279-042X.150057.

26. Ghadeer ARY. Suaifan. A cross-sectional study on knowledge, attitude and behavior related to antibiotic use and resistance among medical and nonmedical university students in Jordan. African J Pharm Pharmacol. 2012; 6(10):763-70. https://doi.org/10.5897/AJPP12.080.

27. Afzal Khan AK, Banu G, Reshma KK. Antibiotic resistance and usage-a survey on the knowledge, attitude, perceptions and practices among the medical students of a southern Indian teaching hospital. J Clin Diagnostic Res. 2013; 7(8):1613-6. https://doi.org/10.7860/JCDR/2013/6290.3230

28. Fejza A, Kryeziu Z, Kadrija K, Musa M. Pharmacy students' knowledge and attitudes about antibiotics in Kosovo. Pharm Pract. 2016;14(1):1-4. https:// doi.org/10.18549/PharmPract.2016.01.715.

29. Kalungia AC, Mwambula H, Munkombwe D, Marshall S, Schellack N, May C, et al. Antimicrobial stewardship knowledge and perception among physicians and pharmacists at leading tertiary teaching hospitals in Zambia: implications for future policy and practice. J Chemother. 2019;31(7-8):37887. https://doi.org/10.1080/1120009X.2019.1622293.

30. Fadare JO, Ogunleye O, liyasu G, Adeoti A, Schellack N, Engler D, et al. Status of antimicrobial stewardship programmes in Nigerian tertiary healthcare facilities: Findings and implications. J Glob Antimicrob Resist. 2019;17:132-6. https://doi.org/10.1016/j.jgar.2018.11.025.

\section{Publisher's Note}

Springer Nature remains neutral with regard to jurisdictional claims in published maps and institutional affiliations.

Ready to submit your research? Choose BMC and benefit from:

- fast, convenient online submission

- thorough peer review by experienced researchers in your field

- rapid publication on acceptance

- support for research data, including large and complex data types

- gold Open Access which fosters wider collaboration and increased citations

- maximum visibility for your research: over $100 \mathrm{M}$ website views per year

At $\mathrm{BMC}$, research is always in progress.

Learn more biomedcentral.com/submissions 